\title{
A practical method for almond cultivar identification and parental analysis using simple sequence repeat markers
}

\author{
Gerald S. Dangl · Judy Yang • \\ Deborah A. Golino · Thomas Gradziel
}

Received: 22 October 2008/Accepted: 29 December 2008/Published online: 8 January 2009

(C) The Author(s) 2009. This article is published with open access at Springerlink.com

\begin{abstract}
Early and accurate identification of almond [Prunus dulcis (Mill.) D.A. Webb] cultivars is critical to commercial growers and nurseries. Previously published simple sequence repeat loci were examined for their ability to distinguish commonly grown almond cultivars. Twelve highly polymorphic loci were selected for their ability to uniquely identify a set of 18 almond cultivars commonly grown in California, many of which are closely related. These markers also allow an accurate assessment of parent/progeny relationships among cultivars. This system can reliably identify at an early stage of development all major California almond cultivars in current production.
\end{abstract}

Keywords Prunus dulcis - Microsatellite markers . DNA fingerprinting · Foundation Plant Services (FPS)

\section{Introduction}

Almonds are California's largest tree nut crop and the state produces over $80 \%$ of the world's supply. Total

G. S. Dangl $(\bowtie) \cdot$ J. Yang · D. A. Golino Foundation Plant Services, University of California, One Shields Avenue, Davis, CA 95616, USA

e-mail: gsdangl@ucdavis.edu

T. Gradziel

Plant Sciences, University of California, One Shields Avenue, Davis, CA 95616, USA almond production in California was a record 1.47 billion pounds in 2007/2008, a $24 \%$ increase over the previous year (ABC 2008). The consistent high demand for California almonds has been met by an increase in acreage planted over each of the past 10 years. In 2007, the estimated bearing acreage was 615,000 (United States Department of Food and Agriculture 2007). The bulk of California almonds are produced by a small number of elite cultivars; 'Nonpareil' alone produces nearly $40 \%$ of the California crop with most remaining cultivars being cross-compatible pollinizers for this self-sterile crop species. In the diploid almond, self-sterility is controlled by a single major (S-) locus, where haploid pollen containing an S-allele in common with either self or cross-pollinated pistils will result in failure of pollen growth to fertilization. Consequently, over $30 \%$ of the remaining production is from only four cultivars: 'Carmel', 'Butte', 'Monterey' and 'Padre' (ABC 2008) which are all fully cross-compatible with 'Nonpareil' and, with the exception of the intersterile 'Butte' and 'Monterey' combination, are inter-compatible with each other (Barckley et al. 2006). With substantial new plantings each year of proven intercompatible cultivars, correct cultivar identification is critical to the continuing success of the industry. However, cultivar identification using morphological characteristics is difficult because trees are planted before distinguishing traits develop.

Simple sequence repeats (SSRs) are used widely for cultivar identification of other woody, clonally 
propagated crops such as grape and walnut (Dangl et al. 2001; Dangl et al. 2005). Foundation Plant Services (FPS) is a service department based in the College of agriculture and environmental sciences at the University of California, Davis. Its mission is to produce, test, maintain, and distribute disease-tested propagation material for use by nurseries and growers throughout the US and worldwide. FPS houses and maintains the foundation collections for the California Department of Food and Agriculture's (CDFA) registration and certification programs for grapevines, deciduous fruit and nut trees, and strawberries. FPS stock qualifies and serves as primary foundation source material for commercial increase for entire industries. Proper identification of cultivars is a critical aspect of FPS's mission.

A major benefit of using DNA markers is that trees can be identified at any developmental stage. SSR markers have been developed for Prunus, including almonds (Martínez-Gómez et al. 2003; Mnejja et al. 2005; Wünsch and Hormaza 2002). However, those reports did not describe streamlined protocols and markers specifically screened for efficient almond cultivar identification. In particular, they did not publish specific allelic data to facilitate development of a universal database of almond SSR marker profiles.

Here we describe an SSR marker system that distinguishes among all commercially important almond cultivars presently grown in California. The small study set contains many closely related cultivars, a particular challenge for a DNA marker-based identification system. The profiles published here uniquely identify all almond cultivars represented in the collection presently maintained by FPS. The procedures presented can be expected to distinguish among all other almond cultivars, and represents a practical system for almond cultivar identification at any developmental stage.

\section{Materials and methods}

Multiple plants of 21 almond cultivars were selected for study (Table 1). Tree leaf samples were from the almond collection at FPS with additional samples from commercial sources and the UC Davis Wolfskill Experimental Orchard included as checks. Young, non-fully expanded leaves were collected and rapidly dried at room temperature using chemical desiccant (Bautista et al. 2008). DNA extraction, PCR, fragment separation, and sizing of amplified fragments were performed according to Bautista et al. (2008) except for multiplex PCR, in which case 0.15 pmo$1 \mathrm{ul}^{-1}$ of both forward and reverse primers for each of three primer pairs was used.

\section{Results and discussion}

An initial set of 14 representative almond cultivars was used to test 53 previously published primer pairs sequenced from several Prunus species for their

Table 1 Almond cultivars used in this study

\begin{tabular}{llll}
\hline Accession & Source & Accession & Source \\
\hline 'ALDRICH' & FPS, CN1 & 'PADRE' & FPS, CN1 \\
'BUTTE' & FPS, CN1 & 'PEERLESS' & FPS, CN1 \\
'CARMEL' & FPS, CN1 & 'PRICE' & FPS \\
'FRITZ' & FPS, CN1 & 'RUBY' & FPS, CN1 \\
'KAPAREIL' & FPS & 'SOLONO'a & CN2, WEO \\
'KOCHI' & FPS & 'SONORA' & FPS, CN1 \\
'MISSION' & FPS, CN1 & 'SWEETHEART' & FPS \\
'MONTEREY' & FPS, CN1 & 'THOMPSON' & CN2, CO2, WEO \\
'NE PLUS ULTRA' & FPS & 'TITAN' & FPS \\
'NONPAREIL' & FPS, CN1 & 'WINTERS' & FPS \\
'NORMAN'a & CO1 & & \\
\hline
\end{tabular}

FPS Foundation Plant Services, U.C. Davis, CN1 commercial nursery 1, CN2 commercial nursery 2, CO1 commercial orchard 1, CO2 commercial orchard 2, WEO Wolfskill Experimental Orchard, U.C. Davis

a Three cultivars tested at nine loci 
ability to consistently amplify polymorphic fragments (Table 2). These primer pairs are described in those original publications as sequences flanking SSR loci. Here, we use the term "locus" to designate the portion of DNA amplified by a particular primer pair and refer to amplified fragments as alleles, though we did not re-sequence the amplified fragments in almond.

Based on the initial screen of 14 almond cultivars, 29 loci were eliminated from further analysis for various reasons (Table 3). Alleles could not be scored for 18 primer pairs: ten primer pairs failed to amplify fragments, six amplified apparently random fragments, and two amplified multiple loci. An additional 11 loci had alleles that could be scored, but did not provide sufficiently useful information to include in the final data set. Four of these were monomorphic for all 14 cultivars in the screen and three had extremely low polymorphism, typically resulting from the presence of one very high frequency allele. Three loci were difficult to score accurately using automated systems due to poor amplification, the presence of single base pair differences in allele lengths and stuttering of the primary fragment. At one locus, all 14 cultivars in the screen were homozygous, resulting in very low polymorphism and suggesting the presence of high frequency null alleles.

Twenty-four loci were selected for further testing: all 12 loci from Table 4 and the 12 loci marked "in data set" from Table 3. These 24 loci reproducibly amplified alleles that behaved as a single Mendelian locus: there were only one or two alleles for a given almond cultivar and these alleles were inherited in a fashion consistent with published pedigrees. The locus BPPCT 038 showed artifacts, however, these were easily distinguished by the analysis software and Mendelian alleles were scored. Reliable polymorphic data at the selected 24 loci were obtained for 18 almond cultivars, including all almond cultivars at FPS (Supplemental data). (Table Supplemental).

Each primer pair was tested under only one standard set of PCR conditions. More primers pairs might have produced useful results under different PCR conditions. However, our goal was to develop a practical forensic "DNA fingerprinting" method to uniquely characterize all almond cultivars and use this method to confirm the identity of each almond tree in the FPS foundation blocks. Adoption of a
Table 2 Origin and citations for tested loci

\begin{tabular}{|c|c|c|}
\hline Locus & Origin & Reference \\
\hline AMPA100 & Apricot & Hagen et al. 2004 \\
\hline AMPA105 & Apricot & Hagen et al. 2004 \\
\hline AMPA118 & Apricot & Hagen et al. 2004 \\
\hline ssrPaCITA10 & Apricot & Lopes et al. 2002 \\
\hline ssrPaCITA12 & Apricot & Lopes et al. 2002 \\
\hline ssrPaCITA14B & Apricot & Lopes et al. 2002 \\
\hline ssrPaCITA15 & Apricot & Lopes et al. 2002 \\
\hline ssrPaCITA18 & Apricot & Lopes et al. 2002 \\
\hline ssrPaCITA19 & Apricot & Lopes et al. 2002 \\
\hline ssrPaCITA2 & Apricot & Lopes et al. 2002 \\
\hline ssrPaCITA23 & Apricot & Lopes et al. 2002 \\
\hline ssrPaCITA25 & Apricot & Lopes et al. 2002 \\
\hline ssrPaCITA27 & Apricot & Lopes et al. 2002 \\
\hline ssrPaCITA4 & Apricot & Lopes et al. 2002 \\
\hline ssrPaCITA7 & Apricot & Lopes et al. 2002 \\
\hline UDAp-410 & Apricot & Messina et al. 2004 \\
\hline UDAp-411 & Apricot & Messina et al. 2004 \\
\hline UDAp-419 & Apricot & Messina et al. 2004 \\
\hline UDAp-420 & Apricot & Messina et al. 2004 \\
\hline UDP96-001 & Peach & Cipriani et al. 1999 \\
\hline UDP96-003 & Peach & Cipriani et al. 1999 \\
\hline UDP96-005 & Peach & Cipriani et al. 1999 \\
\hline UDP98-407 & Peach & Cipriani et al. 1999 \\
\hline UDP98-409 & Peach & Cipriani et al. 1999 \\
\hline ВРРСТ 002 & Peach & Dirlewanger et al. 2002 \\
\hline ВРРСТ 004 & Peach & Dirlewanger et al. 2002 \\
\hline ВРPCТ 006 & Peach & Dirlewanger et al. 2002 \\
\hline ВРРСТ 014 & Peach & Dirlewanger et al. 2002 \\
\hline ВРPCТ 017 & Peach & Dirlewanger et al. 2002 \\
\hline ВРPCТ 034 & Peach & Dirlewanger et al. 2002 \\
\hline ВРPCТ 038 & Peach & Dirlewanger et al. 2002 \\
\hline ВРРСТ 039 & Peach & Dirlewanger et al. 2002 \\
\hline ВРPCТ 040 & Peach & Dirlewanger et al. 2002 \\
\hline ВРРСТ 042 & Peach & Dirlewanger et al. 2002 \\
\hline pchgms 1 & Peach & Sosinski et al. 2000 \\
\hline pchgms 3 & Peach & Sosinski et al. 2000 \\
\hline MA012a & Peach & Yamamoto et al. 2002 \\
\hline MA015a & Peach & Yamamoto et al. 2002 \\
\hline MA017a & Peach & Yamamoto et al. 2002 \\
\hline MA023a & Peach & Yamamoto et al. 2002 \\
\hline MA024a & Peach & Yamamoto et al. 2002 \\
\hline MA027a & Peach & Yamamoto et al. 2002 \\
\hline MA034a & Peach & Yamamoto et al. 2002 \\
\hline MA035a & Peach & Yamamoto et al. 2002 \\
\hline
\end{tabular}


Table 2 continued

\begin{tabular}{lll}
\hline Locus & Origin & Reference \\
\hline MA040a & Peach & Yamamoto et al. 2002 \\
CPSCT012 & Plum & Mnejja et al. 2004 \\
CPSCT026 & Plum & Mnejja et al. 2004 \\
CPSCT042 & Plum & Mnejja et al. 2004 \\
EMPA015 & Sweet cherry & Clarke and Tobutt 2003 \\
EMPA018 & Sweet cherry & Clarke and Tobutt 2003 \\
EMPaS06 & Sweet cherry & Vaughan and Russell 2004 \\
EMPaS10 & Sweet cherry & Vaughan and Russell 2004 \\
EMPaS12 & Sweet cherry & Vaughan and Russell 2004 \\
\hline
\end{tabular}

single protocol for DNA amplification increases productivity and reduces lab errors.

The goal of this study was to develop a method to uniquely identify all current almond cultivars using automated DNA fragment analysis, to use this method to confirm the identity of the almond cultivars at FPS and to elucidate the relationships of the commercially important cultivars grown in California. This study set represents a very narrow germplasm. Such a limited germplasm is a very good sample set for choosing highly polymorphic markers; however, the resulting data set is not the large, diverse database needed to calculate meaningful allele frequencies for probability analysis.

The twelve most informative markers were separated into four groups of three each (Table 4). These groups could be amplified and their fragments analyzed as triplexes, reducing the time and cost of analysis. The first triplex alone is sufficient to uniquely identify all 21 cultivars in the study set (Table 5). We recommend using the first nine markers as a standard profile for almond cultivar identification. Adoption of a standard set of markers for cultivar identification facilitates data sharing and helps correct for variation in data analysis among labs (This et al. 2004). As more profiles for existing almond cultivars are added to this database (Table 5), one would expect more diversity rather than less. Thus, these nine markers, selected for being highly polymorphic in a limited, closely related set of cultivars, can be expected to differentiate among all almond cultivars except those originating as budsports.
Table 3 Results for failed and less polymorphic loci

\begin{tabular}{|c|c|c|}
\hline Locus & Origin & Reference \\
\hline AMPA100 & 4 & In data set \\
\hline AMPA105 & na & No amplification \\
\hline AMPA118 & 1 & Monomorphic \\
\hline ssrPaCITA10 & $\mathrm{Na}$ & Amplified artifacts \\
\hline ssrPaCITA14B & 1 & Monomorphic \\
\hline ssrPaCITA15 & 2 & High homoqygosity \\
\hline ssrPaCITA18 & $\mathrm{Na}$ & Amplified artifacts \\
\hline ssrPaCITA19 & $\mathrm{Na}$ & No amplification \\
\hline ssrPaCITA2 & $\mathrm{Na}$ & No amplification \\
\hline ssrPaCITA23 & $\mathrm{Na}$ & Amplified artifacts \\
\hline ssrPaCITA25 & 2 & Poor amplification \\
\hline ssrPaCITA27 & 1 & Monomorphic \\
\hline ssrPaCITA7 & 3 & Scoring difficulty \\
\hline UDAp-410 & $\mathrm{Na}$ & Amplified artifacts \\
\hline UDAp-411 & $\mathrm{Na}$ & No amplification \\
\hline UDAp-419 & $\mathrm{Na}$ & No amplification \\
\hline UDAp-420 & 5 & In data set \\
\hline UDP96-001 & 3 & In data set \\
\hline UDP96-005 & 4 & In data set \\
\hline UDP98-407 & $\mathrm{Na}$ & Amplified artifacts \\
\hline UDP98-409 & 5 & In data set \\
\hline ВРРСТ 006 & 3 & Low polymorphism \\
\hline ВРРСТ 014 & 3 & In data set \\
\hline ВРРСТ 034 & $\mathrm{Na}$ & Amplified 2 loci \\
\hline ВРРСТ 038 & 6 & In data set \\
\hline ВРPCТ 042 & 3 & Low polymorphism \\
\hline pchgms1 & 4 & In data set \\
\hline pchgms3 & 5 & In data set \\
\hline MA012a & 3 & In data set \\
\hline MA015a & 3 & Low polymorphism \\
\hline MA017a & $\mathrm{Na}$ & Amplified 2 loci \\
\hline MA023a & $\mathrm{Na}$ & Amplified artifacts \\
\hline MA034a & 3 & In data set \\
\hline MA035a & $\mathrm{Na}$ & No amplification \\
\hline CPSCT026 & 1 & Monomorphic \\
\hline CPSCT042 & 3 & In data set \\
\hline EMPA015 & $\mathrm{Na}$ & No amplification \\
\hline EMPA018 & $\mathrm{Na}$ & No amplification \\
\hline EMPaS06 & 3 & Scoring difficulty \\
\hline EMPaS10 & $\mathrm{Na}$ & No amplification \\
\hline EMPaS12 & $\mathrm{Na}$ & No amplification \\
\hline
\end{tabular}

${ }^{a}$ Number of alleles observed in 18 almond cultivars 
Table 4 Suggested loci for almond cultivar identification a Number of alleles observed in 18 cultivars from this study set

\begin{tabular}{lllll}
\hline Locus & Alleles $^{\text {a }}$ & $\begin{array}{l}\text { Size range } \\
\text { (base pairs) }\end{array}$ & $\begin{array}{l}\text { Suggested } \\
\text { triplexes }\end{array}$ & $\begin{array}{l}\text { Suggested } \\
\text { dye }\end{array}$ \\
\hline BPPCT 039 & 8 & $122-180$ & 1 & 6-FAM \\
BPPCT 004 & 7 & $182-216$ & 1 & HEX \\
BPPCT 040 & 8 & $132-148$ & 1 & NED \\
BPPCT 002 & 8 & $199-235$ & 2 & 6-FAM \\
UDP96-003 & 5 & $99-116$ & 2 & HEX \\
MA040a & 7 & $212-259$ & 2 & NED \\
SsrPaCITA12 & 6 & $136-158$ & 3 & 6-FAM \\
MA024a & 7 & $244-250$ & 3 & HEX \\
SsPaCITA4 & 5 & $129-161$ & 3 & NED \\
BPPCT 017 & 5 & $134-168$ & 4 & 6-FAM \\
CPSCT012 & 5 & $143-167$ & 4 & HEX \\
MA027a & 7 & $115-145$ & 4 & NED \\
\hline
\end{tabular}

In addition to allowing an unambiguous identification of almond cultivars, the SSR markers reported here can be used to study cultivar pedigrees. A progeny shares one allele at each locus with each of its parents. This study set of 18 almond cultivars is neither large nor diverse enough to calculate probabilities for parentage analysis. However, a consistent result for both parents and a progeny at all 24 SSR loci provides strong, if not quantifiable, evidence to support the relationship, particularly if it confirms previous reports.

The almond cultivars 'Aldrich', 'Butte', 'Carmel', 'Monterey' 'Norman', 'Price' and 'Thompson' have previously been reported to be chance seedling selections probably originating from 'Nonpareil' $\times$ 'Mission' crosses (Asai et al. 1996; Brooks and Olmo 1997). This preliminary characterization was based on early cross-compatibility studies (Kester et al. 1994) where it was shown that most chanceselection cultivars could be grouped into four crossincompatibility groups $\left(\mathrm{S}_{1} \mathrm{~S}_{7}, \mathrm{~S}_{1} \mathrm{~S}_{8}, \mathrm{~S}_{5} \mathrm{~S}_{7}, \mathrm{~S}_{5} \mathrm{~S}_{8}\right)$. These cross-incompatibility genotypes were presumed to be the result from natural crosses between the dominant cultivar 'Nonpareil' $\left(\mathrm{S}_{7} \mathrm{~S}_{8}\right)$ and the cultivar 'Mission' $\left(\mathrm{S}_{1} \mathrm{~S}_{5}\right)$ which was the major pollenizer for 'Nonpareil' during the early to mid 20th century (Asai et al. 1996; Wood 1925). However, other potential donors of the $S_{1}, S_{5}$ or $S_{7}$ allele have now been identified, including 'Languedoc' $\left(\mathrm{S}_{1} \mathrm{~S}_{5}\right)$, 'Ne Plus Ultra' $\left(\mathrm{S}_{1} \mathrm{~S}_{7}\right)$, and 'Peerless' $\left(\mathrm{S}_{1} \mathrm{~S}_{6}\right)$, (Barckley et al. 2006; Lopez et al. 2006) all of which have been reported to be widely planted in California from the late 19th to mid 20th century (Asai et al. 1996; Wood 1925).

The SSR markers used in this study fully support a 'Nonpareil' by 'Mission' parentage for these chance seedlings. In 'Carmel,' we assumed that a null allele for the MA034a locus is inherited from 'Mission' (Table 6, Bautista et al. 2008). There is no evidence of contributions by either 'Ne Plus Ultra' or 'Peerless' ('Languedoc' unavailable for analysis). In fact, no evidence of genetic contributions from 'Ne Plus Ultra' can be observed in any of the evaluated cultivars despite 'Ne Plus Ultra' being a widely planted cultivar originating from the same seedling block as the original 'Nonpareil' (Wood 1925).

The SSR data does, however, support both 'Fritz' and 'Ruby' as having the cultivar 'Peerless' in their lineage since both have the unique alleles 142 at BPPCT039 and 156 at ssrPaCITA12 markers (Table 5) as well as the unique $\mathrm{S}_{6}$ incompatibility allele. Molecular marker data also support 'Mission' as the other parent (Table 5) as does the presence of the $S_{1}$ incompatibility allele (Barckley et al. 2006). It is assumed the same null allele at MA034a inherited by 'Carmel' is also inherited from 'Mission' by both 'Fritz' and 'Ruby' (Table 6).

Similarly, while the recently released cultivar 'Kochi' was discovered as a volunteer seedling near a 'Drake' almond orchard (Kochi 2004), the SSR data show that it most likely results from a 'Peerless' $\times$ 'Nonpareil' cross. 'Kochi' shares one allele at each locus with both 'Nonpareil' and 'Peerless', including the unique 'Peerless' alleles 142 at 


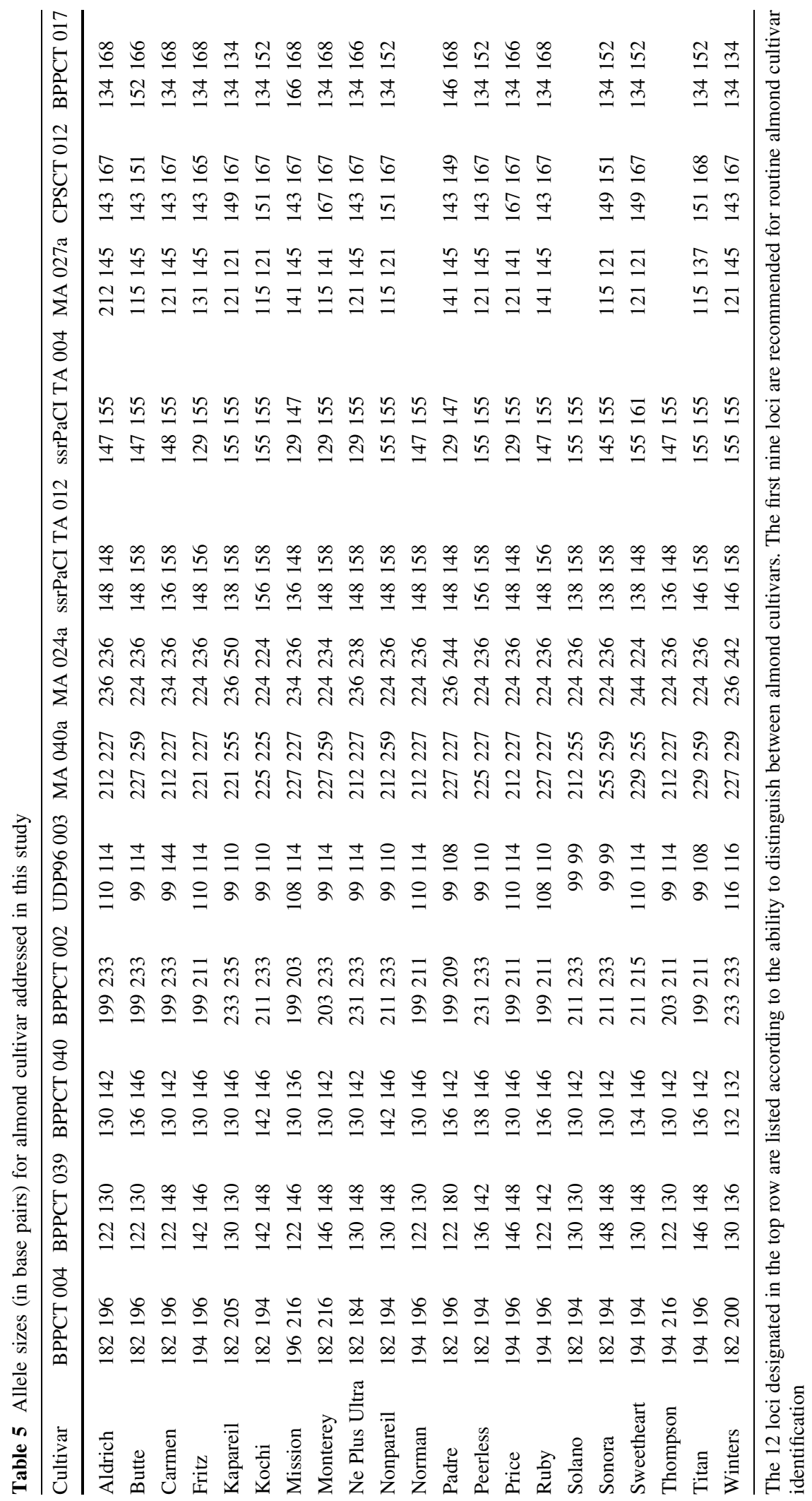


Table 6 Null allele inherited by three 'Mission' progeny

\begin{tabular}{llcll}
\hline Cultivar & \multicolumn{2}{c}{ MA } & 034a initial score & \multicolumn{2}{c}{ MA 034a correct score } \\
\hline Misson & 178 & 178 & 178 & Null \\
Carmel & 222 & 222 & 222 & Null \\
Fritz & 226 & 226 & 226 & Null \\
Ruby & 226 & 226 & 226 & Null \\
\hline
\end{tabular}

Single null alleles will appear homozygous at the given locus. Individuals inheriting the null allele will appear homozygous at that locus

BPPCT039 and 156 at ssrPaCITA12. 'Kochi' also possesses the unique 'Peerless' $\mathrm{S}_{6}$-allele (Barckley et al. 2006).

Molecular markers can also support published parentage by analyzing only parent/progeny pairs, which will share one SSR allele at each locus. Though this analysis does not show the direction of descent (which is the parent and which the progeny), it can be used in conjunction with other information to support reported pedigrees. In this study marker data for 'Padre' support earlier reports of 'Mission' being the seed parent. The data are also consistent with 'Nonpareil' being one parent of 'Kanpareil', 'Solano', 'Sonora' and 'Titan' (Brooks and Olmo 1997). 'Titan's' seed parent is actually known to be 'Tardy nonpareil', a late blooming somatic mutant or "bud-sport" of nonpareil [only rarely are differences between somatic mutants observed with SSR data (Riaz et al. 2002)]. S-allele data are also consistent for the reported parentage of 'Sonora', 'Solano' and 'Kapareil'. There are no S-allele data for 'Titan' which is used primarily as an almond parent in generating almond $x$ peach hybrid rootstocks. Unique molecular marker patterns were also observed for the recent cultivars 'Sweetheart' and 'Winters', supporting the reported use of novel germplasm to incorporate improved productivity and pest resistance to these cultivars (Gradziel et al. 2007; MartínezGómez et al. 2004).

\section{Conclusion}

The goal of this study was to develop a "DNA fingerprinting" method to uniquely identify all almond cultivars and to use this system to confirm the identity of each almond tree in the FPS foundation blocks. Previously published loci were screened with the objective to reduce time and cost of testing. The system developed has streamlined protocols compatible with automated high through-put DNA fragment analysis.

The twelve recommended markers form the basis for a practical method to uniquely identify almond cultivars. The loci show Mendelian inheritance and the profiles are consistent with known parentage and have proven informative in evaluating possible parentage for the many chance seedling selections. The limited database of profiles published here contains all important almond cultivars grown in California. Since these cultivars are readily available worldwide, they provide good reference profiles to facilitate data sharing among different labs.

Acknowledgments The authors would like to thank Dr. Mary Lou Mendum for her expert editing of this manuscript. We would also like to thank Robert Woolley of Dave Wilson nursery for generously providing voucher samples.

Open Access This article is distributed under the terms of the Creative Commons Attribution Noncommercial License which permits any noncommercial use, distribution, and reproduction in any medium, provided the original author(s) and source are credited.

\section{References}

ABC (2008) Almond industry position report, 2007-2008 crop year. Available at http://www.almondboard.com/files/ PDFs/2008.02.pdf

Asai WK, Micke WC, Kester DE, Rough D (1996) The evaluation and selection of current varieties. Almond Production Man 51-59

Barckley KK, Uratsu SL, Gradziel TM, Dandekar AM (2006) Multidimensional analysis of S-alleles from crossincompatible groups of California almond cultivars. J Am Soc Hortic Sci 131:632-636

Bautista J, Dangl GS, Yang J, Reisch B, Stover E (2008) Use of genetic markers to assess pedigrees of grape cultivars and breeding program selections. Am J Enol Vitic 59:248-254

Brooks RM, Olmo HP (1997) The Brooks and Olmo register of fruit and nut varieties, 3rd edn. ASHS Press, Alexandria

Cipriani G, Lot G, Huang WG, Marrazzo MT, Petrtlunger E, Testolin R (1999) AC/GT and AG/CT microsatellite repeats in peach (Prunus persica (L) Batsch): isolation, characterisation and cross-species amplification in Prunus. Theor Appl Genet 99:65-72. doi:10.1007/s001220051209

Clarke JB, Tobutt KR (2003) Development and characterization of polymorphic microsatellites from Prunus avium 'Napoleon'. Mol Ecol Notes 3:578-580. doi:10.1046/ j.1471-8286.2003.00517.x 
Dangl GS, Mendum ML, Prins BH, Walker MA, Meredith CP, Simon CJ (2001) Simple sequence repeat analysis of a clonally propagated species: a tool for managing a grape germplasm collection. Genome 44:432-438. doi:10.1139/ gen-44-3-432

Dangl GS, Woeste K, Aradhya MK, Koehmstedt A, Simon C, Potter D, Leslie CA, McGranahan G (2005) Characterization of fourteen microsatellite markers for genetic analysis and cultivar identification of walnut. J Am Soc Hortic Sci 130:348-354

Dirlewanger E, Cosson P, Tavaud M, Aranzana MJ, Poizat C, Zanetto A, Arus P, Laigret F (2002) Development of microsatellite markers in peach (Prunus persica (L.) Batsch) and their use in genetic diversity analysis in peach and sweet cherry (Prunus avium L.). Theor Appl Genet 105:127-138. doi:10.1007/s00122-002-0867-7

Gradziel T, Lampinen B, Connell J, Viveros M (2007) Winters' almond: an early-blooming, productive and high quality pollenizer for 'Nonpareil. HortScience 42(7): 1725-1727

Hagen LS, Chaib J, Fady B, Decroocq V, Bouchet JP, Lambert P, Audergon JM (2004) Genomic and cDNA microsatellites from apricot (Prunus armeniaca L.). Mol Ecol Notes 4:742-745. doi:10.1111/j.1471-8286.2004.00802.x

Kester DE, Gradziel TM, Micke WC (1994) Identifying pollen incompatibility groups in California almond cultivars. J Am Soc Hortic Sci 119:106-109

Kochi M (2004) Almond tree named 'Kochi'. US Pantent PP15049. Available at http://www.freepatentsonline.com/ PP15049.html. Cited 16 Jul 2008

Lopes MS, Sefc KM, Laimer M, Da Câmara Machado A (2002) Identification of microsatellite loci in apricot. Mol Ecol Notes 2:24-26. doi:10.1046/j.1471-8286.2002. 00132.x

Lopez M, Vargas FJ, Batlle I (2006) Self-(in) compatibility almond genotypes:a review. Euphytica 150:1-16. doi: 10.1007/s10681-005-9009-Z

Martínez-Gómez P, Arulsekar S, Potter D, Gradziel TM (2003) An extended interspecific gene pool available to peach and almond breeding as characterized using simple sequence repeat (SSR) markers. Euphytica 131:313-322. doi:10.1023/A:1024028518263

Martínez-Gómez P, Sánchez-Pérez R, Rubio M, Gradziel TM, Sozzi GO (2004) The application of recent biotechnologies to prunus tree crop breeding. In: Dris $\mathrm{R}$ (ed) Biotechnology in crops. Science Publishers Ltd., Helsinki

Messina R, Lain O, Marrazzo MT, Cipriani G, Testolin R (2004) New set of microsatellite loci isolated in apricot. Mol Ecol Notes 4:432-434. doi:10.1111/j.1471-8286. 2004.00674.x
Mnejja M, Garcia-Mas J, Howard W, Badenes ML, Arus P (2004) Simple-sequence repeat (SSR) markers of Japanese plum (Prunus salicina Lindl.) are highly polymorphic and transferable to peach and almond. Mol Ecol Notes 4:163-166. doi:10.1111/j.1471-8286.2004. 00603.x

Mnejja M, Garcia-Mas J, Howard W, Arus P (2005) Development and transportability across Prunus species of 42 polymorphic almond microsatellites. Mol Ecol Notes 5(3):531-535. doi:10.1111/j.1471-8286.2005.00977.x

Riaz S, Garrison KE, Dangl GS, Boursiquot J-M, Meredith CP (2002) Genetic divergence and chimerism within ancient asexually propagated winegrape cultivars. J Am Soc Hortic Sci 127:508-514

Sosinski B, Gannavarapu M, Hager LD, Beck LE, King GJ, Ryder CD, Rajapakse S, Baird WV, Ballard RE, Abbott AG (2000) Characterization of microsatellite markers in peach (Prunus persica (L.) Batsch). Theor Appl Genet 101:421-428. doi:10.1007/s001220051499

This P, Jung A, Boccacci P, Borrego J, Botta R, Costantini L, Crespan M, Dangl GS, Eisenheld C, Ferreira-Monteiro F, Grando S, Ibáñez J, Lacombe T, Laucou V, Magalhães M, Meredith CP, Milani N, Peterlunger E, Regner F, Zulini L, Dettweiler E (2004) Development of a standard set of microsatellite reference alleles for identification of grape cultivars. Theor Appl Genet 109:1448-1458. doi:10.1007/ s00122-004-1760-3

United States Department of Food and Agriculture (2007) California Almond Forecast. Avaiable at http://www.nass. usda.gov/Statistics_by_State/California/Publications/ Fruits_and_Nuts/200705almpd.pdf. Cited 7 Mar 2008

Vaughan SP, Russell K (2004) Characterization of novel microsatellites and development of multiplex PCR for large-scale population studies in wild cherry, Prunus avium. Mol Ecol Notes 4:429-431. doi:10.1111/j.14718286.2004.00673.x

Wood MN (1925) Almond varieties in the United States. USDA Bull. 1282. Washington DC

Wünsch A, Hormaza JI (2002) Cultivar identification and genetic fingerprinting of temperate fruit tree species using DNA markers. Euthytica 125:59-67. doi:10.1023/A: 1015723805293

Yamamoto T, Mochida K, Imai T, Shi YZ, Ogiwara I, Hayashi T (2002) Microsatellite markers in peach (Prunus persica (L.) Batsch) derived from an enriched genomic and cDNA libraries. Mol Ecol Notes 2:298-310. doi:10.1046/j.14718286.2002.00242.x 